\title{
Identification of potential regional sources of atmospheric total gaseous mercury in Windsor, Ontario, Canada using hybrid receptor modeling
}

\author{
X. Xu' ${ }^{1}$ and U. S. Akhtar ${ }^{1, *}$ \\ ${ }^{1}$ Department of Civil and Environmental Engineering, University of Windsor, Windsor, Ontario, Canada, 401 Sunset Ave, \\ Windsor, Ontario, N9B 3P4, Canada \\ "now at: Department of Chemical Engineering \& Applied Chemistry, University of Toronto, 200 College Street, Toronto, \\ Ontario, M5S 3E5, Canada
}

Received: 30 October 2009 - Published in Atmos. Chem. Phys. Discuss.: 19 November 2009

Revised: 15 June 2010 - Accepted: 7 July 2010 - Published: 3 August 2010

\begin{abstract}
Windsor (Ontario, Canada) experiences transboundary air pollution as it is located on the border immediately downwind of industrialized regions of the United States of America. A study was conducted in 2007 to identify the potential regional sources of total gaseous mercury (TGM) and investigate the effects of regional sources and other factors on seasonal variability of TGM concentrations in Windsor.

TGM concentration was measured at the University of Windsor campus using a Tekran ${ }^{\circledR} 2537 \mathrm{~A} \mathrm{Hg}$ vapour analyzer. An annual mean of $2.02 \pm 1.63 \mathrm{ng} / \mathrm{m}^{3}$ was observed in 2007. The average TGM concentration was high in the summer $\left(2.48 \pm 2.68 \mathrm{ng} / \mathrm{m}^{3}\right)$ and winter $\left(2.17 \pm 2.01 \mathrm{ng} / \mathrm{m}^{3}\right)$, compared to spring $\left(1.88 \pm 0.78 \mathrm{ng} / \mathrm{m}^{3}\right)$ and fall $\left(1.76 \pm 0.58 \mathrm{ng} / \mathrm{m}^{3}\right)$. Hybrid receptor modeling potential source contribution function (PSCF) was used by incorporating 72-h backward trajectories and measurements of TGM in Windsor. The results of PSCF were analyzed in conjunction with the $\mathrm{Hg}$ emissions inventory of North America (by state/province) to identify regions affecting Windsor. In addition to annual modeling, seasonal PSCF modeling was also conducted. The potential source region was identified between $24-61^{\circ} \mathrm{N}$ and $51-143^{\circ} \mathrm{W}$. Annual PSCF modeling identified major sources southwest of Windsor, stretching from Ohio to Texas. The emissions inventory also supported the findings, as $\mathrm{Hg}$ emissions were high in those regions. Results of seasonal PSCF modeling were analyzed to find the combined effects of regional sources, meteorological con-
\end{abstract}

Correspondence to: $\mathrm{X} . \mathrm{Xu}$

(xxu@uwindsor.ca) ditions, and surface re-emissions, on seasonal variability of $\mathrm{Hg}$ concentrations. It was found that the summer and winter highs of atmospheric $\mathrm{Hg}$ can be attributed to areas where large numbers of coal fired power plants are located in the USA. Weak atmospheric dispersion due to low winds and high re-emission from surfaces due to higher temperatures also contributed to high concentrations in the summer. In the winter, the atmospheric removal of $\mathrm{Hg}$ was slow, but strong winds led to more dispersion, resulting in lower concentrations than the summer. Future studies could use smaller grid sizes and refined emission inventories, for more accurate analysis of source-receptor relationship of atmospheric $\mathrm{Hg}$.

\section{Introduction}

Mercury $(\mathrm{Hg})$ is emitted into the atmosphere from both natural and anthropogenic sources. Gaseous elemental $\mathrm{Hg}$ $\left(\mathrm{GEM}, \mathrm{Hg}^{0}\right)$ is chemically inert, exhibits high volatility and low solubility in water. These properties result in high atmospheric residence time, approximately $0.5-2$ years, and thus, $\mathrm{Hg}^{0}$ can be transported over long distances (Poissant et al., 2002). Monitoring of atmospheric elemental $\mathrm{Hg}$ has been conducted in urban, rural, and remote locations around the world (e.g. Sprovieri and Pirrone, 2008; Nguyen et al., 2008; Choi et al., 2009; Fu et al., 2009; Rutter et al., 2009). The majority of the monitoring studies employed Tekran ${ }^{2}$ 2537A $\mathrm{Hg}$ vapour analyzer (Tekran Inc., Toronto, ON, Canada, 2006) which measures total gaseous mercury (TGM). $\mathrm{Hg}^{0}$ constitutes $97-99 \%$ of the total atmospheric $\mathrm{Hg}$ with the remaining 1-3\% encompassing particulate $\mathrm{Hg}$ and reactive $\mathrm{Hg}$

Published by Copernicus Publications on behalf of the European Geosciences Union. 
(Poissant, 2000; Lindberg et al., 2007). Elevated Hg concentrations were observed at remote lake regions far from the anthropogenic sources (Swain et al., 1992; Kellerhals et al., 2003). This indicates long-range transportation and the consequent deposition is the major pathway of $\mathrm{Hg}$ contamination in remote locations. Thus, the emission of $\mathrm{Hg}$ from local sources affects not only the nearby areas; it also affects the global troposphere. Consequently, the observed Hg concentrations at a receptor site are affected by local, regional and global sources.

Hybrid receptor modeling has been used successfully for potential regional source identification of TGM, both for rural and urban areas (e.g. Poissant, 1999; Sigler and Lee, 2006; Han et al., 2007; Choi et al., 2008). This method incorporates backward trajectories and observational $\mathrm{Hg}$ concentrations at the receptor site to obtain the potential source contribution function (PSCF). Results of PSCF provide potential regions that are related to high concentrations observed at the receptor site. This approach is advantageous since receptor concentrations are required, while emission data from individual sources are not essential (Lynam and Keeler, 2006). However, cross examination of potential source regions with emission inventory is desirable to prevent faulty identification. Techniques have also been developed to determine uncertain geographic regions of emission sources (e.g. Owega et al., 2006).

This research was aimed at identifying the potential regional sources of TGM and also the effects of these regional sources on seasonal variability of TGM in Windsor, ON, Canada. Windsor is an industrialized urban city with a population of 200000 (Statistics Canada, 2008). It is situated along the Canada-USA border, across the Detroit River from Detroit (MI). In addition to local sources associated primarily with the automobile industry, Windsor also experiences trans-boundary air pollution since it is downwind of several industrial states including MI, OH and IN. The combined effects of local anthropogenic sources and trans-boundary pollution have resulted with poor air quality in Windsor (Ontario Ministry of Environment, 2005, 2008). Investigation of contributing factors, such as regional transport and re-emission of $\mathrm{Hg}$, is paramount to understanding source and fate of $\mathrm{Hg}$ in an urban environment.

\section{Methodology}

\subsection{Sampling site and instrumentation}

The sampling site, shown in Fig. 1, was located on the campus of the University of Windsor $\left(42^{\circ} 18.27^{\prime} \mathrm{N}, 83^{\circ} 3.98^{\prime} \mathrm{W}\right)$. The site was $27 \mathrm{~m}$ north of Wyandotte Steet West and opposite the Wyandotte Street entrance to the busiest border crossing between Canada and the USA - the Ambassador Bridge. The site was also in close proximity to Huron Church Road (approximately $200 \mathrm{~m}$ west); which is the main corridor lead-

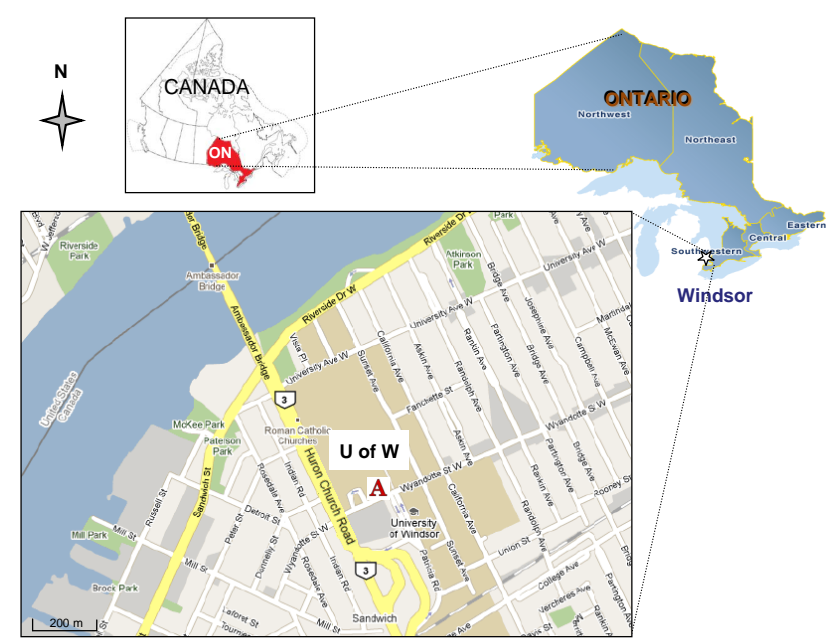

Fig. 1. Map of sampling location at the University of Windsor, Windsor, Ontario, Canada (Letter A indicates the sampling site. Base maps adapted from Google Maps Canada, 2009).

ing to the bridge. Traffic is heavy in these areas due to the border crossing, local traffic and traffic associated with the University of Windsor.

A Tekran ${ }^{\circledR}$ 2537A Hg vapour analyzer was used to measure TGM concentration (mass per standard cubic meter of air, $0{ }^{\circ} \mathrm{C}$ and $1 \mathrm{~atm}$ ) in the ambient air at $5 \mathrm{~min}$ intervals. The sampling inlet height was $5 \mathrm{~m}$ above well kept grass. Particulate matter was removed from the sampling air by a $47 \mathrm{~mm}$ Teflon filter (Tekran Inc., 2006) which was replaced monthly. The $\mathrm{Hg}$ analyzer was calibrated automatically at $23 \mathrm{~h}$ intervals through the built-in permeation $\mathrm{Hg}$ source. Weekly routine maintenance was conducted to ensure proper operation of the equipment throughout the study period. Quality control was applied to exclude data from further analysis in the events of abnormal operation conditions. In April, June, and July of 2007, there were periods when $\mathrm{Hg}$ measurements were missing or deemed invalid primarily due to low baseline readings.

Hourly meteorological data from 2007 were collected from the Environment Canada website (Environment Canada, 2008a). The parameters were measured at Windsor International Airport, located approximately $10 \mathrm{~km}$ southeast of the sampling site. Meteorological data considered in this study include: ambient air temperature, relative humidity, wind speed, and wind direction, for the calculation of seasonal means indicative of weather conditions.

\subsection{Annual and seasonal TGM concentrations}

Five-minute TGM concentrations were averaged to hourly values to maintain consistency with hourly meteorological data and other air quality data collected. Then daily means were calculated. Eastern Standard Time (EST) was used for both the $\mathrm{Hg}$ concentrations and meteorological data. For 
seasonal analysis of TGM concentration, the study period of 2007 was divided into four seasons: winter, spring, summer and fall. The winter months included: December, January and February; spring: March, April and May; summer: June, July and August; fall: September, October and November. The analysis of variance (ANOVA) was used to determine whether the difference in mean concentrations between the seasons is statistically significant. Tukey's test was also used for further comparison of seasonal means. All statistical analyses in this study were performed (at $95 \%$ confidence interval) using MINITAB (Release 14, State College, Pennsylvania, USA).

\subsection{Identification of potential regional sources}

A wind rose was generated to identify prevailing wind directions at Windsor for 2007 using WRPLOT View (Lakes Environmental, 2008). A pollution rose was also generated to identify the wind directions associated with high TGM concentrations in Windsor using Grapher (Version 7, Golden Software Inc., Colorado, USA). Although they do not describe the air mass path before reaching Windsor, the wind rose and pollution rose are simple techniques that facilitate visualization of the wind-concentration relation. The potential source regions were examined further using the hybrid modeling approach which was described previously (Hopke et al., 1995; Polissar et al., 2001). Briefly, the backward trajectories of all days were modeled to identify the regions which the air mass traversed before arriving at the receptor site. Next, the receptor concentrations above a certain threshold were selected. Then the PSCF values of all grid cells in the domain of interest were calculated. A higher PSCF value indicates a higher probability that sources located in the corresponding regions are influencing the receptor site.

\subsubsection{Backward trajectory}

HYSPLIT (HYbrid Single-Particle Lagrangian Integrated Trajectory) Model 4 (Draxler and Rolph, 2003; Rolph, 2003) was used to construct the backward trajectories from the sampling site. Backward trajectories were modeled for 293 days in 2007; when daily TGM concentrations were available. The 72-h run time encompassed most of North America and therefore enabled identification of regional $\mathrm{Hg}$ sources that could affect Windsor TGM concentrations. The start time for trajectory models was zero hour EST (05:00 UTC). This time was chosen for two primary reasons. First, to minimize the effect of local sources and emphasize the effect of regional transport because it was expected that emissions from surfaces and local sources would be at a minimum at zero hour. Second, to enable analysis using daily air quality data such as particulate matter components and volatile organic compounds. The arrival height was chosen as $500 \mathrm{~m}$ above ground level to represent a well-mixed convective boundary layer for regional transport investigation (Gao et al., 1996;
Hafner and Hites, 2003; Begum et al., 2005; Sigler and Lee, 2006). The EDAS $40 \mathrm{~km}$ meteorological data were used since the dataset had the finest spatial resolution for North America that was available on the HYSPLIT website.

\subsubsection{Potential source contribution function (PSCF)}

The potential source region was identified by the geographical region covered by the $72-\mathrm{h}$ trajectories, which was $24^{\circ}$ to $61^{\circ} \mathrm{N}$ and $51^{\circ}$ to $143^{\circ} \mathrm{W}$. For PSCF modeling, the region was divided into $1^{\circ} \times 1^{\circ}$ grid, resulting in 3404 grid cells. From 29372 -h simulations, there were six endpoints per cell on average. The number of back-trajectory endpoints in each cell was counted for all 293 days in 2007 and in all high concentration events. The high concentration events were considered as days when the receptor TGM concentrations (daily means) were above the mean values of the year or a season. The probability of affecting the sampling site by each grid cell is related to the number of back-trajectory endpoints in that cell during high concentration events. Following Han et al. (2007), the PSCF is expressed as:

$\operatorname{PSCF}(i, j)=\left(m_{i j} / n_{i j}\right) W_{i j}$

where $n_{i j}$ and $m_{i j}$ are the total number of back-trajectory segment endpoints that fall into the grid cell $(i, j)$, during all days and in days when receptor concentrations were higher than the criteria value, respectively. A higher ratio of $m_{i j} / n_{i j}$ indicates a higher probability of a particular grid through which a passing air mass would result in a higher receptor concentration. $W_{i j}$ is an empirical weight function proposed by Zeng and Hopke (1989) to reduce the undue influence of small $n_{i j}$ on the PSCF values:

$W_{i j}=\left\{\begin{array}{lc}1.0 & n_{i j}>2 \cdot A v g \\ 0.75 & A v g<n_{i j} \leq 2 \cdot A v g \\ 0.5 & 0.5 \cdot A v g<n_{i j} \leq A v g \\ 0.15 & 0<n_{i j} \leq 0.5 \cdot A v g\end{array}\right.$

where $A v g$ is the average number of trajectory segment endpoints in all cells.

PSCF values were calculated for annual, as well as each season because the meteorological conditions and TGM concentrations are significantly different among the seasons. For annual potential source identification, the annual mean concentration was considered as the criteria value. For seasonal modeling, both the annual and individual seasonal means were used as the criteria values. The use of both values enables identification of the seasonal features of potential source regions as well as a comparison among the seasons.

The total number of endpoints for each grid cell was plotted on a map of North America to identify regions with frequent air mass passage to Windsor. The PSCF values for each cell were also plotted on the map to identify potential regional sources. However, the PSCF map alone is insufficient in establishing source-receptor relationships. In other words, 
regions having high PSCF values would be potential sources for Windsor only if there were significant $\mathrm{Hg}$ emissions. To identify areas with high rates of $\mathrm{Hg}$ air releases, annual $\mathrm{Hg}$ air emissions for states/provinces of USA and Canada were collected from the Toxic Release Inventory (USEPA, 2008) and National Pollutant Release Inventory (Environment Canada, 2008b), respectively. These data were also plotted on the map. All maps were created using ArcGIS Version 9.2 (Environmental Systems Research Institute Inc., Redlands, California, USA).

\section{Results and discussions}

\subsection{Annual TGM concentration}

A total number of 6659 hourly TGM concentrations were collected for 293 days in 2007. The concentrations were in the range of 0.83 to $40.9 \mathrm{ng} / \mathrm{m}^{3}$. The overall average concentration was $2.02 \mathrm{ng} / \mathrm{m}^{3}$ with a standard deviation of $1.63 \mathrm{ng} / \mathrm{m}^{3}$. This annual concentration was higher than the reported Northern Hemisphere background concentration of $1.5-1.7 \mathrm{ng} / \mathrm{m}^{3}$ for $\mathrm{Hg}^{0}$ which constitutes almost $97 \%$ of TGM (Lindberg et al., 2007). The observed concentration was also higher than the average concentration of $1.58 \mathrm{ng} / \mathrm{m}^{3}$, which was observed at all rural sites of the Canadian Atmospheric Hg Measurement Network during 1995-2005 (Temme et al., 2007). However, it was slightly lower than $2.2-4.5 \mathrm{ng} / \mathrm{m}^{3} \mathrm{ob}-$ served in other urban sites in US and Canada, e.g., Toronto $\left(2.48 \mathrm{ng} / \mathrm{m}^{3}\right.$, St. Denis et al., 2006; $4.5 \mathrm{ng} / \mathrm{m}^{3}$, Song et al., 2009), Detroit (2.2 ng/ $\mathrm{m}^{3}$, Liu et al., 2007), Chicago (3.6 ng/ $\mathrm{m}^{3}$, Landis et al., 2002), Milwaukee, WI $\left(2.48 \mathrm{ng} / \mathrm{m}^{3}\right.$, Rutter et al., 2008), New York (3.84 ng/ $\mathrm{m}^{3}$, Capri and Chen, 2002), Broward County Florida $\left(2.8-3.3 \mathrm{ng} / \mathrm{m}^{3}\right.$, Dvonch et al., 1995), and Connecticut $\left(2.19-2.69 \mathrm{ng} / \mathrm{m}^{3}\right.$, Nadim et al., 2001). This places Windsor's ambient $\mathrm{Hg}$ concentrations in between rural and urban sites in US and Canada, indicating moderate contributions of local sources.

\subsection{Seasonal variability of TGM and meteorological pa- rameters}

Statistical summary of seasonal TGM concentrations and meteorological parameters are presented in Table 1. In Windsor, summer conditions are characterized by high temperatures and low wind speeds, while winter conditions are characterized by low temperatures and frequent high wind speeds. The weather patterns are similar in spring and fall, with mild temperatures and medium wind speeds. Seasonal variability in $\mathrm{Hg}$ concentration was also observed. The highest seasonal TGM concentration of $2.48 \mathrm{ng} / \mathrm{m}^{3}$ was seen in the summer, followed by a winter mean of $2.17 \mathrm{ng} / \mathrm{m}^{3}$, whereas the means were lower in spring $\left(1.88 \mathrm{ng} / \mathrm{m}^{3}\right)$ and fall $\left(1.76 \mathrm{ng} / \mathrm{m}^{3}\right)$. The results of ANOVA indicate statistically significant $(p<0.05)$ differences in the mean concentrations among the four seasons. The results of Tukey's test indicate that the mean concentrations for winter and summer were statistically different, while the difference in the mean concentrations of spring and fall were statistically insignificant. Also, the summer and winter means were statistically higher than the means of spring and fall. Higher variability, indicated by the coefficient of variation, was observed in summer and winter, but lower in spring and fall.

One possible reason for such higher TGM concentrations and higher variability in summer is elevated emissions from urban surfaces when temperature is high. Gabriel et al. (2006) observed higher Hg fluxes during summer months, which stem from soil, grass, and pavement in an urban setting. A study conducted at several urban sites in New York (Capri and Chen, 2002) suggested that the emissions from urban surfaces could elevate ambient $\mathrm{Hg}$ concentrations. Another possible reason of high concentrations in summer is the peak electricity demand (USDOE, 2010a) resulting in more coal combustion for power generation. In the US, monthly coal consumptions for electricity generation peak in July and August, followed by a smaller winter peak in December and January (USDOE, 2010b). There was no coal fired power plant in Windsor, however states to the south and southwest of Windsor (e.g., IL, IN, OH, and MI) were the largest source of mercury emission from coal fired power plants in North America (Keating, 2003). There were five coal fired power plants in ON which contributed one third of the provincial Hg emissions (Ontario Clean Air Alliance, 2007). Thus, transportation of airborne $\mathrm{Hg}$ from regional sources could have contributed to higher TGM concentrations. In addition, lower wind speeds during the summer (Table 1) decreased the dilution of atmospheric Hg. Furthermore, a weaker deposition sink to vegetation could be expected in an urban setting where the measurements were taken, compared with rural sites. These resulted in an accumulation of $\mathrm{Hg}$, in spite of the increased atmospheric reaction and removal. High concentrations in winter are attributable to increased energy demand for heating, resulting in increased coal combustion (St. Denis et al., 2006; USDOE, 2010b). Other factors that contributing to elevated $\mathrm{Hg}$ concentrations are the low removal rate and low atmospheric oxidant (e.g., ozone) concentrations (Stamenkovic et al., 2007). Ozone concentrations recorded in an Air Quality Station $1 \mathrm{~km}$ from our measurement site were $11,30,34$, and $20 \mathrm{ppb}$ in winter, spring, summer, and fall of 2007, respectively (Ontario Ministry of Environment, 2010). During the spring and fall, milder temperatures reduce the electricity demand for heating and cooling and consequently lead to lower concentrations and lesser variability. The above analysis suggests that transportation of airborne $\mathrm{Hg}$ from regional sources may significantly influence the overall TGM concentration as well as the seasonal variability in Windsor.

\subsection{Potential regional sources}

Figure 2a shows a wind rose using hourly data for year 2007. The prevailing winds for the study period were between the 
Table 1. Statistical summary of seasonal analysis of hourly TGM concentrations and meteorological parameters in Windsor in 2007.

\begin{tabular}{lllll}
\hline & Winter & Spring & Summer & Fall \\
\hline Concentration $\left(n g / \mathrm{m}^{3}\right)$ & & & & \\
$\mathrm{N}$ & 1962 & 1478 & 1062 & 2157 \\
Min & 1.19 & 0.85 & 0.92 & 0.83 \\
Median & 1.81 & 1.71 & 1.85 & 1.63 \\
Max & 40.9 & 14.3 & 27.9 & 13.6 \\
Mean & 2.17 & 1.88 & 2.48 & 1.76 \\
SD & 2.01 & 0.78 & 2.68 & 0.58 \\
Coefficient of variation (\%) & 93 & 41 & 108 & 33 \\
\hline Meteorological Parameters & & & & \\
Temperature, ${ }^{\circ} \mathrm{C}$, mean (SD) & $-2.9(5.6)$ & $9.8(8.8)$ & $22.8(4.5)$ & $13.3(8.2)$ \\
Relative humidity, \%, mean (SD) & $75.3(12.6)$ & $63.1(16.7)$ & $64.4(15.5)$ & $70.6(16.4)$ \\
Wind speed, km/h, mean (SD) & $18.1(9.5)$ & $17.6(9.7)$ & $12.0(7.3)$ & $13.9(8.5)$ \\
\hline
\end{tabular}

south and the west. The pollution rose in Fig. $2 \mathrm{~b}$ indicates that high TGM concentrations (i.e. the 75 and 95 percentiles) in Windsor were associated mostly with southwest and northeast winds.

Figure 3 plots the total number of endpoints for each grid $\left(1^{\circ} \times 1^{\circ}\right)$ from HYSPLIT simulation, demonstrating the geographical location of air masses arriving in Windsor. It shows air masses that traversed mostly over MI, WI, IL, IN, OH and ON before reaching Windsor. The prevailing air mass direction was between the northwest and the southwest, while fewer grid endpoints were found in the south, east, and northeast, which is consistent with the wind rose (Fig. 2a). However, the northwest direction was not prominent in the wind rose. In the 72-h simulation time, a few trajectories had travelled long distances: from OR and BC in the west and NL in the east.

\subsubsection{Annual PSCF modeling}

For annual PSCF modeling, there were 88 out of 293 available days in 2007 with the daily average concentration greater than the annual mean (i.e. the criteria value), thus were considered as high $\mathrm{Hg}$ concentration days. The PSCF modeling results are plotted in Fig. 4a. High PSCF values were observed in areas indicating $\mathrm{OH}$, IN, IL, MO, KY, and $\mathrm{TN}$ in the southwest as the potential source regions, as well as IA in the west and MI, WI, MN up to MB in the westnorth-west. Relatively high PSCF values were found in the northeast as well. The Gulf of Mexico in the south was also identified as a potential source area. Overall, the major source locations lie to the southwest of Windsor, stretching from $\mathrm{OH}$ to $\mathrm{TX}$, consistent with the pollution rose (Fig. 2b). The potential regions identified from this study are similar to the potential regions, $\mathrm{OH}, \mathrm{IN}$, IL and WI, reported affecting New York (Han et al., 2007), and consistent with sources regions, within the Great Lakes watershed as well as the Ohio
River Valley, reported in the Detroit, MI study (Lynam and Keeler, 2005).

To verify the potentiality of these regions affecting Windsor TGM air quality, a $\mathrm{Hg}$ air emission rate $\left(\mathrm{g} / \mathrm{km}^{2}\right)$ map for the USA and Canada is shown in Fig. 4b. The annual emission rate for each state/province was calculated by dividing the total air emission of all $\mathrm{Hg}$ compounds by the respective state/province area for the year 2006. The overall Hg emission rate was higher in the USA $\left(6.18 \mathrm{~g} / \mathrm{km}^{2}\right)$ compared to in Canada $\left(0.76 \mathrm{~g} / \mathrm{km}^{2}\right)$. The highest $\mathrm{Hg}$ emission rates of 33 to $51 \mathrm{~g} / \mathrm{km}^{2}$ were observed in IN, OH, PA, WV, and AL. Other high $\mathrm{Hg}$ emitting states were IL, KY, TN, LA, and GA. Thus, states that are southwest, south and southeast of Windsor were found to have high $\mathrm{Hg}$ releasing sources. In Fig. $4 \mathrm{a}$, the Gulf of Mexico was identified as a source region of $\mathrm{Hg}$. Annual atmospheric deposition, including both wet and dry, was 25 tons to the surface water of the Gulf of Mexico and an additional 22 tons of $\mathrm{Hg}$ discharged into the Gulf from the Mississippi River (Neff, 2008). Although air emissions from oceans were not included in Fig. 4b, re-emission of $\mathrm{Hg}$ and long-range transport from the marine boundary layer of the Gulf of Mexico could be a potential source of $\mathrm{Hg}$ in Windsor. Results obtained from the emission inventory analysis supports the findings of the PSCF modeling (Fig. 4a): regions located in the southwest significantly affect Windsor TGM concentrations.

\subsubsection{Seasonal PSCF modeling}

For seasonal modeling, both annual mean and respective seasonal means (Table 1) were used for each season as the criteria value. The same weight function was used for all four seasons as in annual modeling. For comparison of potential regions among the seasons, the same color scheme for weighted PSCF values was used in the plots for all four seasons (Figs. 6 and 7). 
(a)

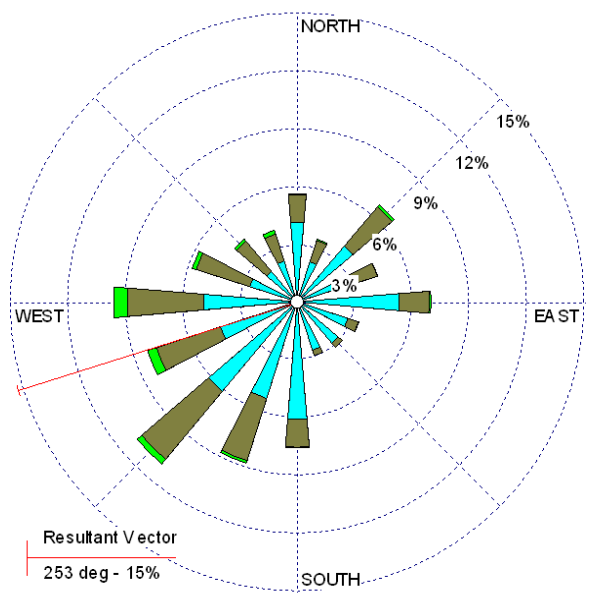

(b)

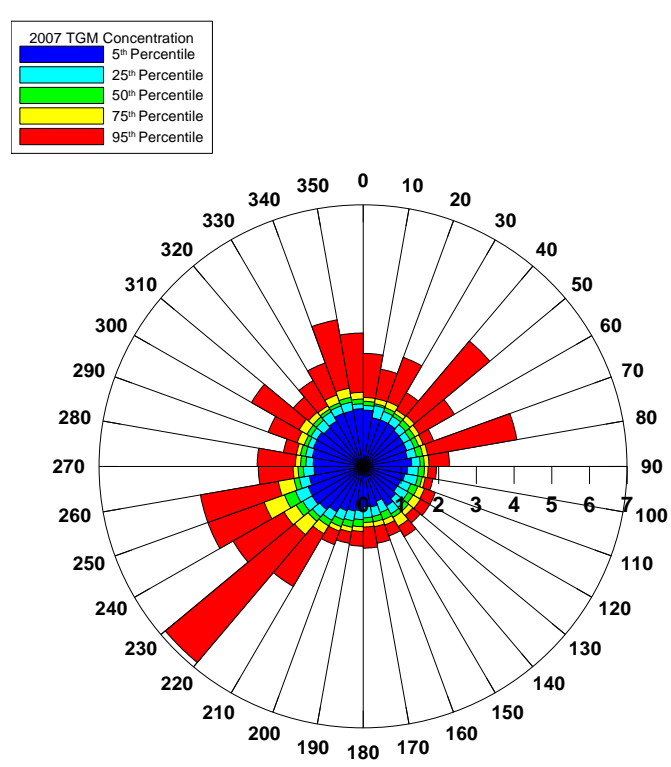

Fig. 2. (a) Wind rose, and (b) $\mathrm{Hg}$ pollution rose $\left(\mathrm{ng} / \mathrm{m}^{3}\right.$ ) for Windsor, 2007, using hourly data.

Results of seasonal PSCF modeling using annual mean as the criteria value are presented in Fig. 5. In summer, significant source areas were identified southwest of Windsor, from $\mathrm{OH}$ to TX as shown in Fig. 5c, including MI, OH, IN, $\mathrm{IL}, \mathrm{MO}, \mathrm{KS}, \mathrm{OK}$, and TX. Presence of potential sources over a wide range of areas was observed in the winter, between the southwest and northwest regions, also in the north (ON) and in the south (Gulf of Mexico) (Fig. 5a). In spring, significant source areas were identified in the southwest (Fig. 5b) as in summer. The potential sources for these periods were located in OH, IN, IL, MO, and TN. Sources were also identified in the northeast, along the Ontario-Quebec corridor in spring. In fall (Fig. 5d), the southwest (OH, IN, IL and MO) were identified as source regions, although the PSCF values were lower compared with other seasons.

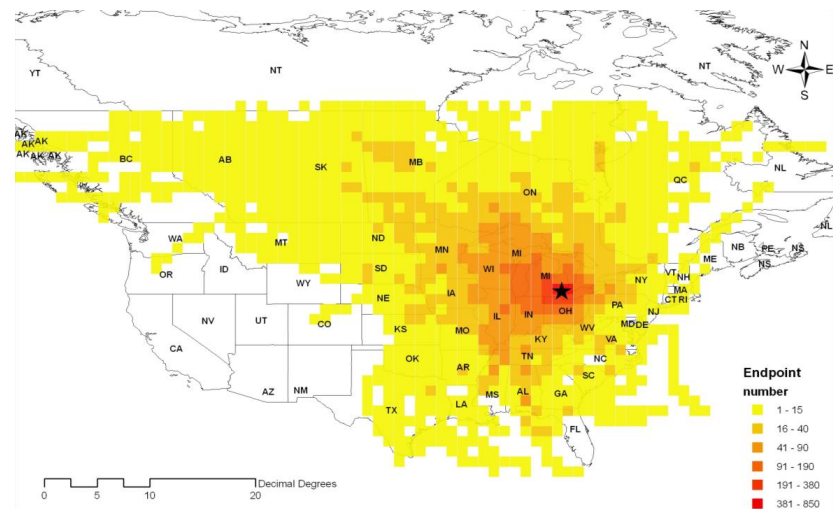

Fig. 3. Map of total number of end points in each grid cell (Star indicates Windsor).
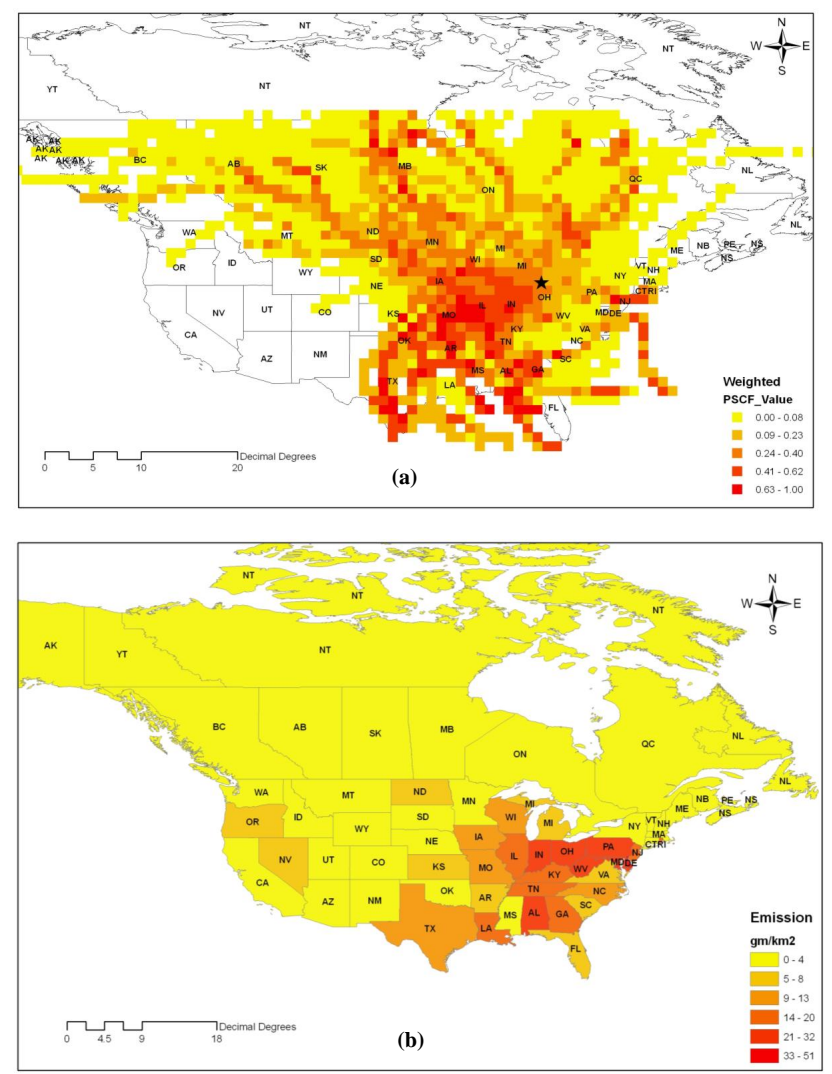

Fig. 4. (a) Map of weighted PSCF values for Windsor (Star indicates Windsor), and (b) annual (2006) air emission rate $\left(\mathrm{g} / \mathrm{km}^{2}\right)$ of all mercury compounds in the USA and Canada. Sources of emission data: Toxic Release Inventory (USEPA, 2008) and National Pollutant Release Inventory (Environment Canada, 2008b).

The seasonal modeling depicts the seasonal distribution of potential source areas, which was marginalized by the annual modeling. Significant source areas were identified in specific directions for each season. More potential source regions were identified in summer and winter as the number 

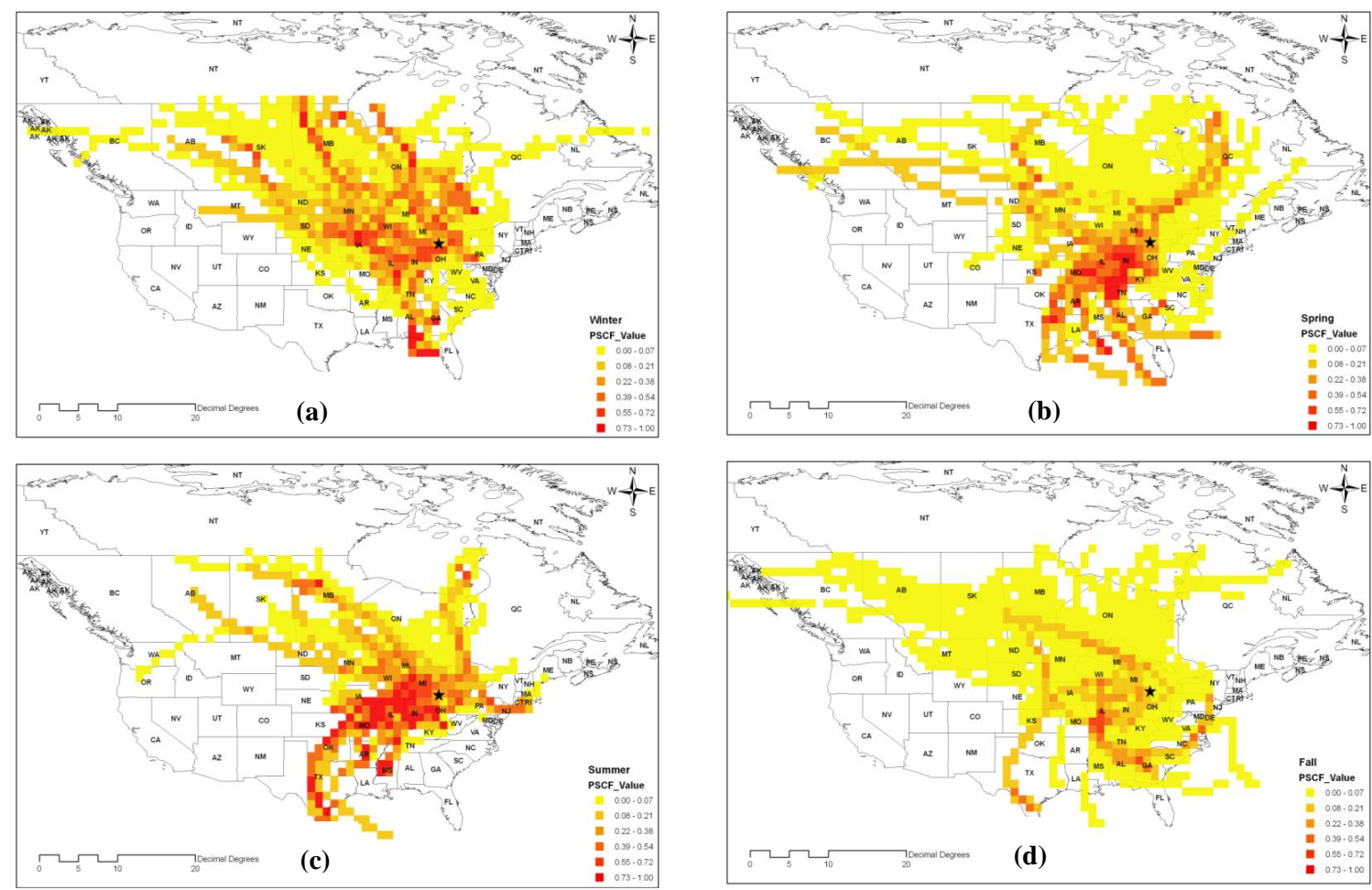

Fig. 5. Weighted PSCF for Windsor in (a) winter, (b) spring, (c) summer and (d) fall, using the annual mean of $2.02 \mathrm{ng} / \mathrm{m}^{3}$.
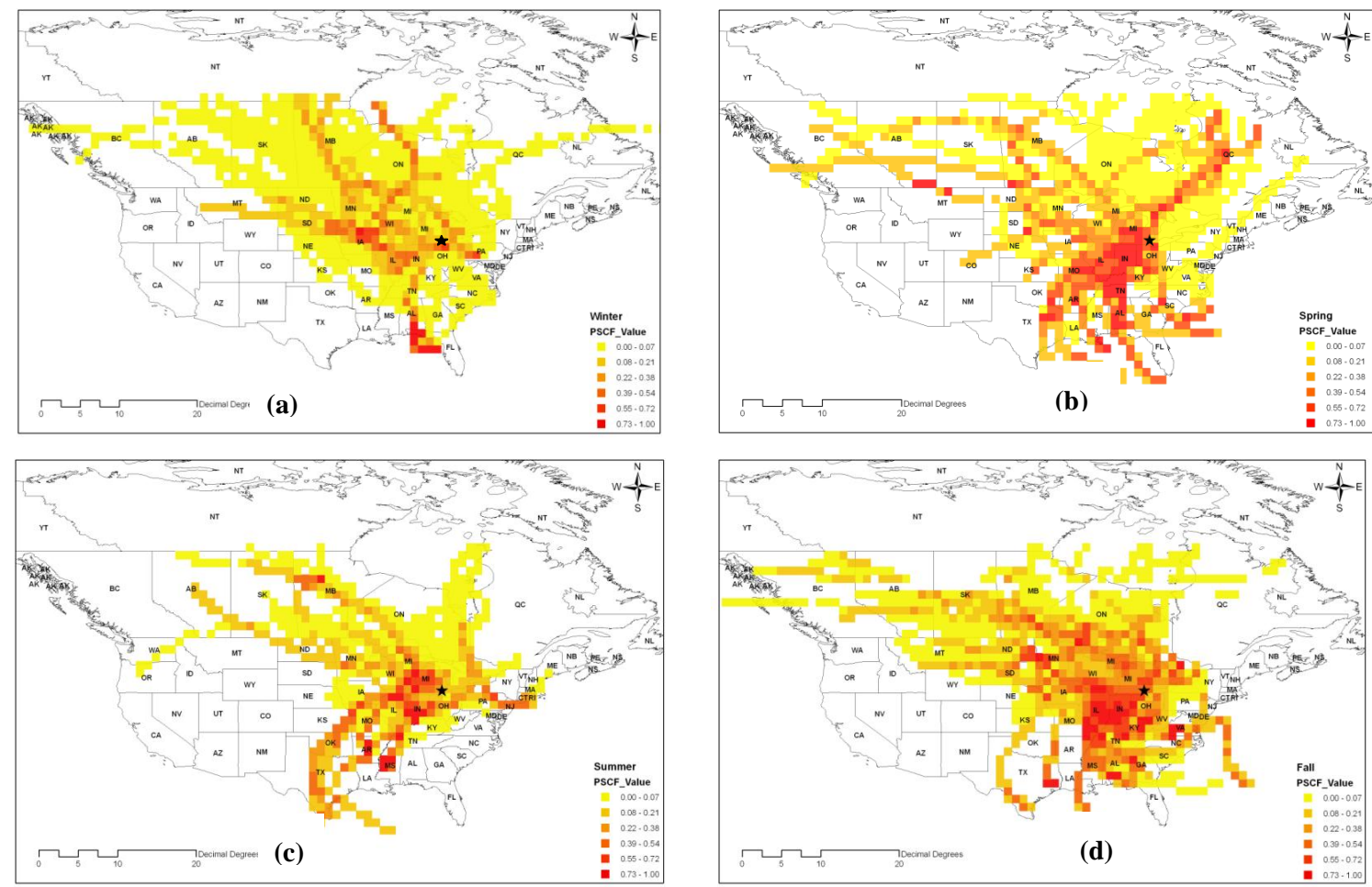

Fig. 6. Weighted PSCF for Windsor in (a) winter, (b) spring, (c) summer, and (d) fall, using seasonal means. 
Table 2. Source regions responsible for high TGM concentrations in Windsor.

\begin{tabular}{lll}
\hline Season & Using annual mean & Using seasonal mean \\
\hline \multirow{2}{*}{ Winter } & $\begin{array}{l}\text { OH, IN, IL, IA, MB, SK, } \\
\text { AL, Gulf of Mexico, ON }\end{array}$ & $\begin{array}{l}\text { IA, AL, Gulf of } \\
\text { Mexico }\end{array}$ \\
Spring & IN, IL, MO, KY, TN, TX & $\begin{array}{l}\text { MI, OH, IN, IL, IA, } \\
\text { TN, AL, MO, AR, } \\
\end{array}$ \\
& & TX, QC, ON, AB \\
Summer & MI, OH, IN, IL, IA, MO, & MI, IN, IL, AR, MS \\
& AR, MS, KS, TX & \\
Fall & IL, MO & OH, IN, IL, MO, KY, \\
& & AL, TX, WI, MN, \\
& & ND, VA, ON, MB \\
\hline
\end{tabular}

of concentration exceedances above the annual mean were higher in these two seasons ( 30 and 25 days, respectively), compared to in spring and fall (20 and 13 days, respectively). Therefore, this method may not be well suited for comparison among the four seasons.

Figure 6 illustrates the seasonality in potential sources using respective seasonal means. The maximum number of exceedances over the criteria value was observed in fall with 36 days, followed by spring with 27 and lastly, both winter and summer with 15 . As expected, more potential source areas were identified with the seasonal mean than with an annual mean (Fig. 5) in winter and summer, while less occurred in spring and fall. This is because less days were modeled in summer (Fig. 6c) using the seasonal mean $\left(2.48 \mathrm{ng} / \mathrm{m}^{3}\right)$ as opposed to the annual mean $\left(2.02 \mathrm{ng} / \mathrm{m}^{3}\right)$. MI, OH, IN, IL, AR, MS were identified as significant source regions in summer. Similarly, the potential sources in the south and in the west are responsible for high concentrations $\left(>2.17 \mathrm{ng} / \mathrm{m}^{3}\right)$ in winter (Fig. 6a).

To further identify the regions responsible for high concentration days for each season, Table 2 lists all states/provinces in which there were at least two consecutive grids with weighted PSCF values $>0.55$, i.e. a high possibility of being a source region. Some regions such as $\mathrm{MI}, \mathrm{OH}$, IN, IL were identified in more than one season. Between the two modeling approaches, i.e. using seasonal and annual means, the consistency is more pronounced in the summer and winter. From the analysis it can be concluded that days with high $\mathrm{Hg}$ concentrations in the summer, spring and fall were affected mostly by the regions to the west and southwest of Windsor (MI, OH, IL and IN), with some influence of the east $(\mathrm{ON})$ in the spring. High concentrations in the winter were affected by regions in the west and southwest $(\mathrm{OH}, \mathrm{IN}, \mathrm{IL}$ and IA) and some remote sources in the south (AL, Gulf of Mexico).
The seasonal analysis also identified that in each season the regional influences, in terms of emissions and meteorology, affect Windsor's Hg concentration by slightly different mechanisms. Along with high surface emission, regional sources, the coal fired power generation sector in particular, also contributed to the high concentrations observed in summer. A number of coal fired power plants are located in the southwest region of Windsor. This region was also identified as potential source region in seasonal PSCF modeling. Thus air masses carrying $\mathrm{Hg}$ from southwest of Windsor at low wind speed (less dilution of $\mathrm{Hg}$ ) lead to elevated concentrations in Windsor. For the other three seasons, the picture was more complex. In winter, anthropogenic emissions are also high due to high energy consumption for heating. The southwest contributions were not as strong as in summer (Figs. 6 and 7), however there was long-range transport from the south, i.e. AL and Gulf of Mexico. On the other hand, higher wind speeds (Table 2) led to more dispersion. Also, there are less chemical transformation and deposition due to low temperatures. The net effect of these major factors led to elevated TGM concentrations in winter. In spring and fall, though the air mass came mostly from the southwest regions, $\mathrm{Hg}$ emissions from surfaces and anthropogenic sources were both low compared to summer and winter, resulting in lower TGM concentrations in Windsor. The results of the seasonal analysis are consistent with principal component analysis, another receptor modeling approach by Akhtar (2008). The identified top four factors were fossil fuel combustion, meteorological conditions, photochemical reactions, and coal combustion.

The seasonal PSCF modeling reveals seasonal features which cannot be ascertained from annual modeling alone. Between the two schemes, maps created using the annual mean identify the distribution of potential sources among the four seasons since the same criteria value was applied, as pointed out by some previous studies (e.g. Han et al., 2007; Choi et al., 2008). However, seasons with means below the annual average will have fewer high concentration days modeled in comparison with other seasons. The use of respective seasonal means enables the identification of potential sources responsible for high concentration days in each season, thus a comparison among the four seasons is possible. The similarity between Figs. 6 and 7 is apparent, indicating that the modeling results are not very sensitive to a few high concentration days. These events were present in modeling using either seasonal or annual mean, but not part of the counter approach. For example, there were 15 and 25 days in winter for modeling with seasonal and annual means, respectively. Thus, there were 10 more events modeled with annual mean than with seasonal. The difference in the days had generally not affected the outcome. However, this may not be the case for other datasets. For identification of potential sources, the application of both annual and seasonal means was useful for seasonal PSCF modeling. It was recommended using both methods in the seasonal modeling. When the resources are 
limited, however, the use of seasonal means is preferred.

It should be noted that $\mathrm{Hg}$ may be picked up by air masses close to the receptor site and therefore biasing the PSCF results. In Windsor, only two facilities reported $\mathrm{Hg}$ emissions which totaled $16 \mathrm{~kg}$ per year (Environment Canada, 2008b). However, the annual $\mathrm{Hg}$ disposal from power plants, incinerators, and industrial facilities in Wayne County (USEPA, 2008), where Detroit is located, was over $800 \mathrm{~kg}$ in 2007. A short term spatial variability study was conducted in Windsor in 2006 using a mobile lab. Among the 13 sites monitored, the locations closest to the two $\mathrm{Hg}$ emitting facilities experienced higher concentrations. Concentrations were relatively high at sites close to the Detroit River, likely due to $\mathrm{Hg}$ emissions from sources in Detroit. Details of the study can be found in Akhtar (2008). It is recommended to compare the $\mathrm{Hg}$ measurements at Windsor with that from some rural sites in the region to quantify the enrichment due to local sources.

A major shortcoming of the hybrid receptor modeling method is that the uncertainty of potential source regions could be large due to the exclusion of emissions in the analysis. As a result, faulty identification of source regions is not unlikely. The use of by state/province emission inventories in this study provides a mechanism to screen potential source regions qualitatively. However, $\mathrm{Hg}$ emission inventories may have much higher uncertainty than that of some other pollutants. In the past few years, methods that enhance the conventional PSCF have been explored. Hopke et al. (2005) have employed residence time analysis and made direct comparisons between the PSCF results and emission inventories using a spatial autocorrelation statistic. Han et al. (2005) have reported better correlation with the emission inventory by incorporating backward dispersion and deposition into PSCF. A more comprehensive approach is developed by Han et al. (2007), where PSCF, residence time weighted concentration and simplified quantitative transport bias analysis were used in conjunction with multi-site measurements to identify important mercury source regions for New York State. More thorough evaluation of PSCF using sophisticated transport-chemistry models should also be further explored.

An important future consideration would be to further break down the simulation areas into smaller grid sizes with better refined emission inventories, thus allowing for more detailed and more accurate analysis of source-receptor relationship of atmospheric $\mathrm{Hg}$. This kind of inventory should include seasonal emissions of individual point sources, such as: coal fired power plant, metal processing, and waste incineration, as well as county wide emissions of area sources. Additionally, future studies should investigate the sensitivity of PSCF results to some modeling parameters. One of them is the use of higher criteria values such as the 85 th percentile (Sigler and Lee, 2006) instead of the means. Another parameter is the temporal resolution, i.e. the number of trajectories per sample or per day. Some studies have used multiple trajectories each day (e.g. Han et al., 2005, 2007; Sigler and
Lee, 2006). Air trajectories can change quickly as illustrated in the Supplemental Figure S1, where HYSPLIT simulation plots at a frequency of four times per pay for all odd dates in 2007 are provided.

\section{Conclusions}

Hybrid receptor modeling using HYSPLIT and PSCF was analyzed in conjunction with the $\mathrm{Hg}$ emission inventory of North America, to identify the potential source regions affecting Windsor's TGM concentrations. From the annual PSCF modeling, the major sources were identified southwest of Windsor stretching from $\mathrm{OH}$ to TX. Potential sources in the northwest (MI to MB), the west (IA), the northeast (ON) and the south (the Gulf of Mexico) were also identified.

Seasonal modeling identified potential source regions in specific directions for each season. High $\mathrm{Hg}$ concentration days in summer, fall and spring were affected mostly by the regions west/southwest of Windsor, where there are a large number of coal fired power plants. In winter, high concentrations were affected by regions in the west/southwest and some remote sources in the south including the Gulf of Mexico. Weather related processes, i.e., re-emission, chemical reactions and sequential atmospheric removal by dry/wet deposition, atmospheric mixing and dispersion also play important roles in modulating seasonal $\mathrm{Hg}$ concentrations. The seasonal modeling was found beneficial for analysis of major factors affecting seasonal variability of $\mathrm{Hg}$ concentrations in an urban setting.

\section{Appendix A}

\section{State abbreviations}

Alabama (AL), Arkansas (AR), British Columbia (BC), Georgia (GA), Iowa (IA), Illinois (IL), Indiana (IN), Kentucky (KY), Louisiana (LA), Manitoba (MB), Michigan (MI), Minnesota (MN), Mississippi (MS), Missouri (MO), Newfoundland and Labrador (NL), Ohio $(\mathrm{OH})$, Ontario $(\mathrm{ON})$, Oregon (OR), Pennsylvania (PA), Tennessee (TN), Texas (TX), West Virginia (WV), Wisconsin (WI).

\section{Supplementary material related to this article is available online at: http://www.atmos-chem-phys.net/10/7073/2010/ acp-10-7073-2010-supplement.pdf.}

Acknowledgements. We are thankful to Tekran Inc. for their kind contribution toward the purchasing of the Mercury Analyzer and for their technical supports. The authors gratefully acknowledge the NOAA Air Resources Laboratory (ARL) for the provision of the HYSPLIT transport and dispersion model and/or READY website (http://www.arl.noaa.gov/ready.html) used in this publication. Special thanks to Marsha Pereira, Joseph Amato and Harshal Patel from the University of Windsor for editorial assistance. 
We also gratefully appreciate the suggestions of the anonymous reviewers. Funding of this research work was provided by the Natural Sciences and Engineering Research Council of Canada (NSERC) and the University of Windsor.

Edited by: K.-H. Kim

\section{References}

Akhtar, U. S.: Atmospheric Total Gaseous Mercury Concentration Measurement in Windsor: A study of Variability and Potential Sources, M.A.Sc. Thesis, University of Windsor, Windsor, Ontario, Canada, 2008.

Begum, B. A., Kim, F., Jeong, C. H., Lee, D. W., Hopke, P. K.: Evaluation of the potential source contribution function using the 2002 Quebec forest fire episode, Atmos. Environ., 39, 3719$3724,2005$.

Capri, A. and Chen, Y. F.: Gaseous elemental mercury fluxes in New York city, Water Air Soil Pollut., 140, 371-379, 2002.

Choi, E. M., Kim, S. H., Holsen, T. M., and Yi, S. M.: Total gaseous concentrations in mercury in Seoul, Korea: local sources compared to long-range transport from China to Japan, Environ. Pollut., 157, 816-822, 2009.

Choi, H. D., Holsen, T. M., and Hopke, P. K.: Atmospheric mercury $(\mathrm{Hg})$ in the Adirondacks: concentrations and sources, Environ. Sci. Technol., 42, 5644-5653, 2008.

Draxler, R. R. and Rolph, G. D.: HYSPLIT (HYbrid Single-Particle Lagrangian Integrated Trajectory) Model, NOAA Air Resources Laboratory, Silver Spring, MD, USA, available online at: www. arl.noaa.gov/ready/hysplit4.html, 2003.

Dvonch, J. T., Vette, A. F., Keeler, G. J., Evans, G., and Stevens, R.: An intensive multi-site pilot study investigating atmospheric mercury in Broward County, Florida, Water Air Soil Pollut., 80, 169-178, 1995

Environment Canada, Climate Data Online: www.climate. weatheroffice.ec.gc.ca/climateData/canadae.html, last access: March 2008, 2008a.

Environment Canada, National Pollutant Release Inventory: www. ec.gc.ca/pdb/npri/npri/online/data/e.cfm, last access: March 2008, 2008b.

Fu, X., Feng, X., Wang, S., Rothenberg, S., Shang, L., Li, Z., and Qiu, G.: Temporal and spatial distributions of total gaseous mercury concentrations in ambient air in a mountainous area in southwestern China: Implications for industrial and domestic mercury emissions in remote areas in China, Sci. Total Environ., 407, 2306-2314, 2009.

Gabriel, M. C., Williamson, D. G., Zhang, H., Brooks, S., and Lindberg, S.: Diurnal and seasonal trends in total gaseous mercury flux from three urban ground surfaces, Atmos. Environ., 40, 4269-4284, 2006.

Gao, N., Hopke, P. K., and Reid, N. W.: Possible sources of some trace elements found in airborne particles and precipitation in Dorset, Ontario, J. Air Waste Manage. Assoc., 46, 1035-1047, 1996.

Hafner, W. D. and Hites, R. A.: Potential sources of pesticides, PCBs, and PAHs to the atmosphere of the Great Lakes, Environ. Sci. Technol., 37, 3764-3773, 2003.

Han, Y. J., Holsen, T. M., Hopke, P. K., and Yi, S. M.: Comparison between back-trajectory based modeling and Lagrangian backward dispersion modeling for locating sources of reactive gaseous mercury, Environ. Sci. Technol., 39(6), 1715-1723, 2005.

Han, Y. J., Holsen, T. M., and Hopke, P. K.: Estimation of source locations of total gaseous mercury measured in New York State using trajectory based models, Atmos. Environ., 41, 6033-6047, 2007.

Hopke, P. K., Li, C. L., Ciszek, W., and Landsberger, S.: The use of bootstrapping to estimate conditional probability fields for source locations of airborne pollutants, Chemom. Intell. Lab. Syst., 30(1), 69-79, 1995.

Hopke, P. K., Zhou, L., and Poirot, R. L.: Reconciling trajectory ensemble receptor model results with emissions, Environ. Sci. Technol., 39(20), 7980-7983, 2005.

Keating, M.: Mercury and Midwest Power Plants, Clean Air Task Force: www.catf.us/publications/reports/Midwest_Mercury.pdf, last access: March 2007, 2003.

Kellerhals, M., Beauchamp, S., Belzer, W., Blanchard, P., Froude, F., Harvey, B., McDonald, K., Pilote, M., Poissant, L., Puckett, K., Schroeder, B., Steffen, A., and Tordon, R.: Temporal and spatial variability of total gaseous mercury in Canada: Results from the Canadian Atmospheric Mercury Measurement Network (CAMNet), Atmos. Environ., 37, 1003-1011, 2003.

Lakes Environmental, WRPLOT View, Wind Rose Plots for Meteorological Data, www.weblakes.com/products/wrplot/index.html, last access: May 2008, 2008.

Landis, M., Vette, A. F., and Keeler, G. J.: Atmospheric mercury in the Lake Michigan basin: influence of the Chicago/Gary urban area, Environ. Sci. Technol., 36, 4508-4517, 2002.

Lindberg, S. E., Bullock, R., Ebinghaus, R., Engstrom, D., Feng, X., Fitzgerald, W., Pirrone, N., Prestbo, E., and Seigneur, C.: A synthesis of progress and uncertainties in attributing the sources of mercury in deposition, Ambio, 36, 19-32, 2007

Liu, B., Keeler, G. J., Dvonch, J. T., Barres, J. A., Lynam, M. M., Marsik, F. J., and Morgan, J. T.: Temporal variability of mercury speciation in urban air, Atmos. Environ., 41, 1911-1923, 2007.

Lynam, M. M. and Keeler, G. J.: Automated speciated mercury measurements in Michigan, Environ. Sci. Technol., 39, 92539262, 2005.

Lynam, M. M. and Keeler, G. J.: Source-receptor relationships for atmospheric mercury in urban Detroit, Michigan, Atmos. Environ., 40, 3144-3155, 2006.

Nadim, F., Perkins, C., Liu, S., Carley, R. J., and Hoag, J. E.: Long-term investigation of atmospheric mercury contamination in Connecticut, Chemosphere, 45, 1033-1043, 2001.

Neff, J.: Mercury in the Gulf of Mexico: do offshore oil \& gas facilities contribute?, www.battelle.org/Environment/publications/ envupdates/summer2002/article6.stm, last access: March 2008.

Nguyen, H. T., Kim, K. H., Kim, M. Y., Kang, C. H., and Shim, S. G.: Mercury in air impacted by strong industrial activities, Chemosphere, 71, 2017-2029, 2008.

Ontario Clean Air Alliance, An OCAA Air quality Report, OPG: Ontario's Pollution Giant: www.cleanairalliance.org/resource/ opgiant.pdf, last access: March 2007.

Ontario Ministry of Environment, Transboundary Air Pollution in Ontario. www.ene.gov.on.ca/envision/techdocs/5158e_index htm, 2005, last access: April 2008.

Ontario Ministry of Environment, Air Quality in Ontario-2007 Report, Environmental Monitoring and Reporting Branch, Ontario 
Ministry of the Environment: www.ene.gov.on.ca/publications/ 6930e.pdf, 2008, last access: April 2008.

Ontario Ministry of Environment, Historical Air Quality Pollutant Data. http://www.airqualityontario.com/history/, last access: June 2010.

Owega, S., Evans, G. J., Khan, B., Jervis, R. E., and Fila, M.: Application of a counting technique to determine certain and uncertain geographic regions of emission sources, Ecol. Modell, 192, 627-636, 2006.

Poissant, L.: Potential sources of atmospheric total gaseous mercury in the St. Lawrence River valley, Atmos. Environ., 33, 2537-2547, 1999.

Poissant, L.: Total gaseous mercury in Québec (Canada) in 1998, Sci. Total Environ., 259, 191-201, 2000.

Poissant, L., Dommergue, A., and Ferrari, C. P.: Mercury as a global pollutant, Journal De Physique, IV, 12, 143-160, 2002.

Polissar, A. V., Hopke, P. K., and Harris, J. M.: Source regions for atmospheric aerosol measured at Barrow, Alaska, Environ. Sci. Technol., 35, 4212-4226, 2001.

Rolph, G. D.: Real-time Environmental Applications and Display System (READY), available online at: www.arl.noaa.gov/ready/ hysplit4.html, NOAA Air Resources Laboratory, Silver Spring, MD, USA, last access: April 2008, 2003.

Rutter, A. P., Schauer, J. J., Lough, G. C., Snyder, D. C., Kolb, CJ., Klooster, S. V., Rudolf, T., Manolopoulos, H., and Olson, M. L.: A comparison of speciated atmospheric mercury at an urban center and an upwind rural location, J. Environ. Monit., 10, 102108, 2008.

Rutter, A. P., Snyder, D. C., Stone, E. A., Schauer, J. J., GonzalezAbraham, R., Molina, L. T. Márquez, C., Cárdenas, B., and de Foy, B.: In situ measurements of speciated atmospheric mercury and the identification of source regions in the Mexico City Metropolitan Area, Atmos. Chem. Phys., 9, 207-220, doi:10.5194/acp-9-207-2009, 2009.

Sigler, J. M. and Lee, X.: Recent trends in anthropogenic mercury emission in the northeast United States. J. Geophys. Res., 111, D14316, doi:10.1029/2005JD006814, 2006.

Song, X., Cheng, I., and Lu, J.: Annual atmospheric mercury species in downtown Toronto, Canada, J. Environ. Monit., 11, 660-669, 2009.
Sprovieri, F. and Pirrone N.: Spatial and temporal distribution of atmospheric mercury species over the Adriatic Seas, Environ. Fluid Mech., 8, 117-128, 2008.

Stamenkovic, J., Lyman, S., and Gustin, M. S.: Seasonal and diel variation of atmospheric mercury concentrations in the Reno (Nevada, USA) Airshed, Atmos. Environ., 41, 6662-6672, 2007.

Statistics Canada, 2006, Community Profiles, http://www12. statcan.ca/census-recensement/index-eng.cfm, last access: April 2008.

St. Denis, M., Song, X., Lu, J. Y., and Feng, X.: Atmospheric gaseous elemental mercury in downtown toronto, Atmos. Env., 40, 4016-4024, 2006.

Swain, E. B., Engstrom, D. R., Brigham, M. E., Henning, T. A, Brezonik, P. L.: Increasing rates of atmospheric mercury deposition in midcontinental North America, Science, 257, 784-787, 1992.

Tekran Inc.: Tekran 2537A Mercury Vapour Analyzer User's Manual, Toronto, Canada, 2006.

Temme, C., Blanchard, P., Steffen, A., Banic, C., Beauchamp, S., Poissant, L., Tordon, R., and Wiens, B.: Trend, seasonal and multivariate analysis study of total gaseous mercury data from the Canadian Atmospheric Mercury Measurement Network (CAMNet), Atmos. Environ., 41, 5423-5441, 2007.

United States Department of Energy (USDOE). Energy Information Administration. Electric Power Industry 2008: Year in Review. http://www.eia.doe.gov/cneaf/electricity/epm/table2_ 1_a.html, last access: June 2010, 2010a.

United States Department of Energy (USDOE). Energy Information Administration: Coal: Consumption for Electricity Generation. http://www.eia.doe.gov/cneaf/electricity/epm/table2_1_ a.html, last access: June 2010, 2010b.

United States Environmental Protection Agency (USEPA): Toxic Release Inventory: www.epa.gov/mercury/regs.htm, last access: April 2008.

Zeng, Y. and Hopke, P. K.: A study of the sources of acid precipitation in Ontario, Canada, Atmos. Environ., 23, 1499-1509, 1989. 